\title{
Socioeconomic Status, English Exposure and CLIL Motivation in High and Low Exposure CLIL Groups
}

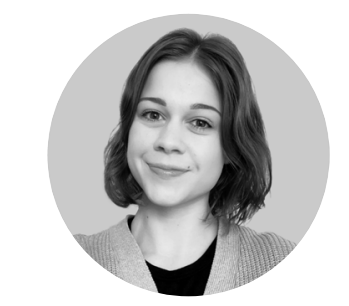

FORREST LEAH TOMPKINS

UNIVERSIDAD AUTÓNOMA DE MADRID

leah.tompkins@uam.es

C ontent and Language Integrated Learning (CLIL) programs are often praised for bringing equity to foreign language learning (e.g., Lorenzo et al., 2021). However, streaming processes, such as those of the Community of Madrid Bilingual Program, may reinforce inequalities among students (e.g., Llinares \& Evnitskaya, 2021). In line with recent research comparing CLIL students' affective factors in high exposure (HE) and low exposure (LE) tracks (e.g., Fernández-Agüero \& Hidalgo-McCabe, 2020), the present study examines possible differences in the socioeconomic status (SES), CLIL motivation, and exposure to English of HE and LE students at a bilingual (Spanish/ English) secondaryschool in a low SES town in Madrid. Aquestionnaire measuring cultural and economic capital, CLIL motivation, and teachers' use of English was administered to a sample of LE and all HE students in year 10. Results show that the students of lowest and highest SES were concentrated in LE and HE tracks, respectively. In the LE track, CLIL and English teachers used English less frequently, and students exhibited lower intrinsic motivation. For students with lower English proficiency (often of lower SES), access to the cultural and economic capital afforded by knowledge of English may be constrained by fewer meaningful learning opportunities.

\section{KEYWORDS:}

CLIL, bilingual education, socioeconomic status, motivation, secondary

\begin{abstract}
1 gunos estudios han puesto en valor los programas de Aprendizaje Integrado de Contenido y Lenguas Extranjeras (AICLE) por aportar equidad al aprendizaje de lenguas extranjeras (p. ej., Lorenzo et al., 2021). Sin embargo, la distribución del los alumnos en grupos, como ocurre en el Programa Bilingüe de la Comunidad de Madrid, puede reforzar las desigualdades sociales entre ellos (p. ej., Llinares y Evnitskaya, 2021). En línea con recientes investigaciones que comparan los factores afectivos de alumnos en grupos de alta exposición (AE) y de baja exposición (BE) (p. ej., FernándezAgüero y Hidalgo-McCabe, 2020), el presente estudio examina las posibles diferencias en el nivel socioeconómico (NSE), motivación hacia AICLE y exposición al inglés de alumnos de AE y BE en un instituto bilingüe de una zona de bajo NSE en Madrid. Para ello, se administró un cuestionario a una muestra de alumnos de BE y a todos los de AE. Los resultados muestran que los alumnos de menor y mayor NSE se concentraron en BEy AE, respectivamente. En BE, los profesores de AICLE e inglés usaban este idioma con menos frecuencia y los alumnos mostraban menor motivación intrínseca. Para los alumnos con menor dominio del inglés (muchas veces de menor NSE), el acceso al capital social y cultural que ofrece el conocimiento del inglés puede verse limitado por una falta de oportunidades de aprendizaje significativo.
\end{abstract}

PALABRAS CLAVE:

AICLE, educación bilingüe, nivel socioeconómico, motivación, secundaria 


\section{Introduction}

1 n recent decades, the European Union has set its sights on increasing multilingualism to "unite people," "strengthen intercultural understanding," and enhance employability and mobility (European Commission, n.d.). Educational institutions throughout Europe have responded by dedicating more time and resources to foreign language learning and teaching, especially in the form of Content and Language Integrated Learning (CLIL) programs (Fernández-Agüero \& Hidalgo-McCabe, 2020). In Spain, one of the most extensive is the Comunidad de Madrid Bilingual Program (MBP). Compared with programs in other autonomous communities, its admission process is unique: families choose whether to send their children to bilingual or monolingual schools, and bilingual schools place, or "stream," students in high exposure (HE) or low exposure (LE) tracks based on English proficiency. Both self-selection and streaming have come under scrutiny, as they may lead to "cream skimming" in which the most socioeconomically and academically select students enter bilingual schools and HE tracks, respectively (Mediavilla et al., 2019; Fernández-Agüero \& HidalgoMcCabe, 2020). Such criticism has led researchers to begin an in-depth investigation of the streaming process and its impact on students' English use, cognitive engagement, motivation, and affective factors. For instance, Llinares \& Evnitskaya (2021) found that HE students used English more frequently than their LE counterparts during lessons taught in English, and teachers engaged their higher order thinking skills to a greater extent, regardless of the language of instruction. As for affect, HE students expressed feelings

${ }^{66}$ Both self-selection

and streaming have come under scrutiny, as they may lead to "cream skimming" in which the most socioeconomically and academically select students enter bilingual schools and HE tracks, respectively (Mediavilla et al., 2019; Fernández-Agüero \& Hidalgo-McCabe, 2020)." of superiority in relation to their LE peers (Fernández-Agüero \& Hidalgo-McCabe), and LE students exhibited lower levels of motivation, perhaps due to the curricular differences between the tracks (Somers \& Llinares, 2021). However, to my knowledge there has not yet been any comprehensive research into socioeconomic factors which may mediate these differences between HE and LE, and studies into student motivation have primarily taken place in schools of medium to high socioeconomic status (SES) (e.g., Somers \& Llinares, 2021). This scenario motivates the present work, a case study which explores the following research questions at one lower SES school in the MBP:

1. Are there differences between HE and LE tracks in student SES?

2. Are there differences between HE and LE tracks in the extent to which CLIL and English teachers use the English language?

3. Are there differences between HE and LE tracks in intrinsic CLIL motivation?

4. Are there differences between HE and LE tracks in instrumental CLIL motivation?

Due to the small scale of the research project, the answers to these questions will not be generalizable to the MBP: they represent only the grade 10 students at the selected school. The author does not intend to draw conclusions about the whole program, but rather to carry out a preliminary, quantitative analysis of the socioeconomic landscape of HE and LE tracks in a working-class context, which has been somewhat neglected in recent research on CLIL in Madrid, and to explore the possibility/necessity of conducting largescale studies on this matter in the future.

\section{An Overview of the Literature}

A s early as 1995, the European Commission set forth a $1+2$ policy under which Europeans would learn two foreign languages in addition to their mother tongue (European Commission, 1995). One increasingly popular means of meeting this goal without adding hours to the school day is CLIL: teaching content subjects through a vehicular language different from the mother tongue. CLIL has expanded rapidly throughout Europe because, in addition to efficiently increasing exposure to the target language, it is thought to help learners gain communicative competence "more quickly, naturally and effortlessly" than they would through traditional foreign language teaching (Comunidad de Madrid, 2016, p. 55). Moreover, CLIL in Spain has been credited with making foreign language learning more accessible because it is offered at public primary and secondary schools at no additional cost to the parents (Fernández-Agüero \& HidalgoMcCabe, 2020; Lorenzo et al., 2021). 
Indeed, Andalusia established its first bilingual schools in low income rural and urban areas, hoping to bridge the gap in foreign language acquisition between students with and without access to classes at private language academies (Lorenzo et al., 2021). In their 2021 study, Lorenzo et al. proved that bilingual schools also promote educational equity in several subjects besides English. Whereas monolingual schools exhibit a "staircase effect," in which students' SES directly correlates with their academic performance, no such correlation is observed at Andalusian bilingual schools. On the contrary, student performance at lower SES bilingual schools is on par with that of higher SES bilingual schools, which Lorenzo et al. (2021) attribute to a "language across the curriculum" approach that supports the academic literacy of lower SES students. As opposed to monolingual schools, which often take for granted students' knowledge of the language of instruction, successful bilingual schools incorporate greater language awareness into their curriculums and may thus moderate differences in language capital that could otherwise lead to differences in educational outcomes (Lorenzo et al., 2021).

To contribute to educational equity, however, programs must be accessible to all students. This may not be the case in the Community of Madrid, where both school choice and streaming (the grouping of students based on academic performance) determine admission to bilingual programs, potentially exacerbating the social stratification of the student population (Mediavilla et al., 2019; Fernández-Agüero \& Hidalgo-McCabe, 2020). Regarding school choice, Mediavilla et al. (2019) found that "cream skimming" occurs when parents decide between a monolingual or bilingual school for their children, resulting in bilingual schools becoming "more select in socioeconomic and academic terms" than monolingual schools (p. 14). Perceptions of bilingual schools as academically rigorous institutions lead families to self-select; higher SES students "have abandoned monolingual public schools, to mostly concentrate in bilingual schools," whereas lower SES students remain in monolingual schools, perhaps with the hope of better ensuring academic success (Mediavilla et al., 2019, p. 18). As a result, higher SES students may develop additional language capital while lower SES students are left behind.

Within bilingual secondary schools, students' exposure to English is determined by their performance on an external English proficiency examination at the end of primary school: those who pass may choose to participate in the HE track, and those who do not are placed in the LE track, studying fewer and less academically salient subjects in English. In both CLIL and non-CLIL programs, streaming is observed to negatively impact socioeconomically disadvantaged students, who are less likely to enter more selective tracks (see Van Mensel et al., 2020 and Horn, 2013, respectively). Similarly, MBP HE students in Fernández-Agüero and Hidalgo-McCabe's (2020) study reported greater use of private teachers than their LE peers when preparing for the English proficiency examination, which may indicate higher levels of social and cultural capital (p. 8). Once admitted, not only do HE students "receive more opportunity to develop English in contexts that will allow them to transfer that proficiency later on," but educators, parents and students alike also confer greater prestige onto the HE program because it offers more cognitively demanding subjects in English (Somers \& Llinares, 2021, p. 852). From a sociological perspective, the HE CLIL program is an opportunity to accumulate both cultural and symbolic capital; whom such capital is awarded to determines which social groups benefit most from the MBP.

Students themselves are not naïve to the long-term educational and occupational advantages of participating in the HE track. In Fernández-Agüero and Hidalgo-McCabe (2020), students in both tracks perceived the HE track as more beneficial for their futures, associating it with greater job opportunities and social mobility. Furthermore, HE students "thought that they belonged to an elite, to the best class, thus denoting that they felt superior" (p. 11). One can imagine that such awareness of unequal opportunities would impact student motivation. Somers and Llinares (2021) found "low-intensity students to be less strongly motivated, intrinsically and instrumentally," perhaps because they "have much fewer CLIL subjects (6h per week), which are also less "academically inclined" (p. 849). Although both groups recognize the importance of English proficiency for their future, as demonstrated in high levels of instrumental motivation, "low proficient students find themselves in a situation where because of the limited exposure and academic status of the subjects, CLIL is unable to do much for them in the future" (p. 14).

The research outlined above suggests that the MBP may play a role in reinforcing existing inequalities among students. Once (relatively higher SES) students choose to attend a bilingual school, social and economic capital can buy them access to the academic support they need to enter HE tracks (Fernández-Agüero \& Hidalgo-McCabe, 2020). If admitted, they continue to accumulate cultural and symbolic capital in the form of foreign language knowledge, which gives them a competitive edge in an increasingly globalized job market. While students of low SES are welcome to participate in the MBP, school choice and streaming are more likely to exclude them than their high SES peers. Certainly, "the study of English is always a class-inflected phenomenon" (Block, 2012, p. 202). Despite such alarming observations, to my knowledge there has yet to be any comprehensive research into differences in SES between HE and LE CLIL tracks in the MBP. Fernández-Agüero and Hidalgo-McCabe (2020) commented on differences in social and economic capital within a larger study, but it was not the focus of their research. Thus, the present study intends to take a first step into researching the socioeconomic landscape of the MBP. As class may reveal how students relate to second language learning (Block, 2012), differences in student motivation are also examined, as well as teachers' use of English. 


\section{${ }^{66}$ The present study intends to take a first step into researching the socioeconomic landscape of the MBP. As class may reveal how students relate to second language learning (Block, 2012), differences in student motivation are also examined, \\ as well as teachers' use of English."}

\section{Theoretical Background}

$\mathrm{T}$ he present study adopts Bourdieu's (1977, 1986) understanding of social class to operationalize SES ${ }^{1}$, as is commonplace in the disciplines of sociology and sociolinguistics (Block, 2014). Bourdieu (1986) defines social class as a combination of economic, social and cultural capital, which underly "the regularities of the social world" (p. 241) and impede true meritocracy. Thus, an individual's position in a social space is determined by their accumulated capital in relation to that of others. In his 1986 work, he defines the forms of capital as follows:

- Economic capital comprises income and other financial and/or property assets which may be directly converted into money.

- Cultural capital comes in an embodied state (e.g., knowledge, accent, posture), objectified state (e.g., cultural goods: books, art, instruments, etc.) and institutionalized state (e.g., academic qualifications), all of which may be indirectly converted into money by, for example, providing access to employment.

- Social capital consists of one's social connections and the extent of their respective capital, which may also be indirectly converted into money when, for example, a family friend helps one get a job.

Across disciplines, SES is often operationally defined as a composite variable including education (cultural capital), income (economic capital) and occupation (primarily economic capital) (e.g., National Center for Educational Statistics, 2012), leaving aside social capital, perhaps due to the difficulty of operationalizing it in survey research. However, this operationalization is not always possible when underage participants are involved due to privacy laws and school regulations, so other indicators of cultural and economic capital, such as books or other home possessions, may also be employed (Broer et al., 2019; National Center for Educational Statistics, 2012). An SES index may be created by combining the selected indicators of cultural and economic capital and weighting them in different ways (see National Center for Educational Statistics, 2012 and Gil Flores, 2013), but here each one is examined individually to achieve a more detailed understanding of the distribution of resources in HE and LE tracks.

As regards students' motivation, the present study employs Somers and Llinares's (2021) notions of intrinsic and instrumental "CLIL motivation." Unlike previous approaches to motivation in bilingual programs, which have dealt with content and second language motivations separately, this construct is specific to motivation for learning content and language in an integrated way. Adapting Gardner's (1985) instrumental and integrative motivation to the CLIL context, the authors define intrinsic motivation as "the participation in CLIL classes for its inherent satisfaction," and instrumental motivation as the perceived "usefulness of participating in a CLIL programme as a means to achieve an ulterior motive" (in this case academic or professional) (Somers \& Llinares, 2021, p. 844). As in Somers and Llinares (2021), this study measures both forms and compares the values in HE and LE.

\section{Materials and Methods}

to the present study, a 52-item questionnaire was developed to measure student demographics, socioeconomic status, classroom dynamics, and CLIL motivation. Demographic and SES measurements were taken from a questionnaire used by the Spanish Ministry of Education (2017, May 6) to ensure that they were appropriate to use with minors in a school setting. Measurements of classroom dynamics and CLIL motivation were taken from Somers and Llinares (2021) with permission from the authors. Participants were informed that their responses were anonymous and that their participation was voluntary.

\section{Research Context}

T he study was carried out at a bilingual high school in a working to lower-middle class town south of Madrid capital. As compared to the Community of Madrid as a whole, the town has lower income per capita and considerably higher unemployment rates (Comunidad de Madrid, 2015, p. 31). The percentage of indefinite work contracts is lower than in the Community of Madrid, suggesting less job security (Comunidad de Madrid, 2020). The town also has a greater percentage of immigrants: $18.3 \%$ of the population is of foreign nationality, as compared to $13.2 \%$ in the Community of Madrid as a whole (Instituto de Estadística de la Comunidad de Madrid, 2019). Nearly half 
(46.9\%) of the immigrant population comes from Romania, followed by Morocco (20.6\%) and various Latin American countries (15.6\%), primarily Colombia, Peru and Ecuador. Based on these demographics, the overall SES of the school is expected to be quite low; all analyses will be relative to this context.

\section{Participants}

$\mathrm{T}$ he questionnaire was administered to a total of 34 students in their last year of obligatory secondary education (grade 10). At this high school, there are only eight students in the HE track and 115 in the LE track, for which reason participants included all HE students and a small sample of LE students: 14 students from the "academic math/science" group and 12 from the "humanities" group. All LE participants had the same English teacher, who described one group as "high performing" and the other as "low performing." Students at this school are grouped according to their academic interests, not their level of English, but teachers observe correlations between English level and group assignment because LE students exhibiting lower overall academic performance, including level of English, tend to concentrate in the humanities group, which is perceived as "easier." Both groups were included in this study to adequately represent the LE track. As per the Spanish Ministry of Education, Youth and Sport's (2017, April 7) order, all grade 10 students receive one hour of English lessons per day (5 hours per week), as well as Physical Education in English (2 hours per week). The HE track also learns History and Geography in English (3 hours per week), along with their weekly tutorial (1 hour per week), accounting for an additional 4 hours per week.

\section{Instrument}

$\mathrm{F}$ or this paper, the responses to 16 items on the questionnaire were analyzed. The first portion, taken from the Spanish Ministry of Education, Culture and Sport (2017, May 6), deals with student demographics and socioeconomic status. It asks for participants' gender, year of birth, and whether they and their parents were born in Spain. Then various socioeconomic indicators are measured, which the present study has sorted into those reflecting cultural capital and economic capital. Thus, cultural capital has been operationalized as: the highest level of education achieved by each parent (selected from a list of options available in the Spanish educational system), and the number of books in the home. Economic capital has been operationalized as: the current or most recent occupation of each parent (never employed; unspecialized workers; specialized workers and artisans; workers specialized in agriculture, livestock or fishing; factory workers; hospitality workers and salespeople; workers in personal services, protection and security; small business owners; managerial positions; technicians or assistants; executives and high commissioners; professionals; or not applicable (due to the absence of a parent)), the number of IT devices in the home, and the number of people in the household.

The second portion, taken from Somers and Llinares (2021), measures use of English in the classroom and student motivation. First, it asks how often participants' English language and CLIL teachers use the English language in their respective subjects to explain/teach materials and to give instructions, measured on a Likert scale from 1 (always) to 6 (never) for each category. These two items correspond with Christie's (2005, as cited in Llinares \& Evnitskaya, 2021) instructional and regulative registers, respectively. Then it assesses motivation according to participants' agreement with a set of statements, also measured on a Likert scale from 1 (strongly agree) to 5 (strongly disagree). The translations of these statements belong to Somers and Llinares (2021, p. 847):

Intrinsic motivation:

- I enjoy learning subjects through English.

- I enjoy participating in English in subjects taught through English.

- I enjoy the classes taught through English.

Instrumental motivation:

- Studying subjects in English is useful for me because I'll need it for my future studies.

- Studying subjects in English is useful for me in finding a good job.

- Studying subjects in English is useful for me because people will respect me more if I speak English well.

- Studying subjects in English is useful for me because English is an important language in the world.

\section{Results}

\section{Student Demographics}

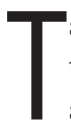
able 1 shows a breakdown of student demographics in the HE and LE tracks. In terms of gender, both tracks are evenly split between girls and boys. There are considerable differences in year of birth, suggesting that more students in the LE track repeated a grade. The HE track is more academically select, which was also reflected anecdotally when an LE student referred to the HE students as "los listillos" while filling out the questionnaire. Regarding immigrant status, the percentage of second-generation immigrant students is similar in both tracks, but there are no first-generation immigrant students in the HE track, as compared with $15.38 \%$ in LE. 
Table 1

Student Demographics in HE and LE

\begin{tabular}{lcc}
\hline Student gender & High exposure & Low exposure \\
\hline male & $4(50 \%)$ & $13(50 \%)$ \\
female & $4(50 \%)$ & $13(50 \%)$ \\
\hline Year of birth & High exposure & Low exposure \\
\hline 2005 & $7(87.5 \%)$ & $15(57.69 \%)$ \\
2004 & $1(12.5 \%)$ & $6(23.08 \%)$ \\
2003 & 0 & $4(15.38 \%)$ \\
unknown & 0 & $1(3.85 \%)$ \\
\hline Immigrant status & High exposure & Low exposure \\
\hline student & 0 & $4(15.38 \%)$ \\
1 parent & $1(12.5 \%)$ & $2(7.69 \%)$ \\
2 parents & $2(37.5 \%)$ & $11(42.31 \%)$ \\
\hline
\end{tabular}

\section{Socioeconomic Indicators}

I he results from the socioeconomic portion of the questionnaire are reported in their respective subsections: "Cultural Capital," which includes parents' level of education and number of books, and "Economic Capital," which includes parents' level of occupation, IT devices in the home, and household size. For simplicity and space reasons, the options for educational and occupational levels were condensed from those offered on the original questionnaire and instead follow Gil Flores's (2013) model. In education, the options "no studies" and "incomplete primary/secondary studies" were condensed into a single category, as were the two options for voluntary, non-university studies, and the two options for graduate-level university studies. In occupation, the "skilled workers and artisans," "skilled workers in agriculture, cattle raising and fishing" and "machinery operators" were combined into one category; workers in "hospitality and sales" and "personal services, security and protection" were combined into one category; and finally "small business owners," "administrative employees" and "technicians and support workers" were also combined. The percentages of "unknown" responses refer to students who either did not answer the corresponding question or whose response was not interpretable (e.g., they marked multiple boxes where only one should have been selected or wrote words instead of numbers). Further explanation of "unknown" responses and their relationship with other SES indicators can be found below in the section "Unknown Responses in Educational and Occupational Levels."

\section{Cultural Capital}

Institutional and objectified forms of cultural capital were operationalized as parents' educational level and number of books in the home, respectively. To calculate central tendencies, both indicators were placed on a numerical scale: educational level from 0 (unknown) to 4 (university studies) and books from 1 ( 0 to 10 books) to 5 (>200 books). The results show that the cultural capital of HE students was only slightly higher than that of LE students: the median education level was 2 (primary or secondary studies) for parents of students in both tracks, while the median number of books was 2.5 (between 11 to 50 and 51 to 100) for $\mathrm{HE}$ and 2 (11 to 50$)$ for LE.

Table 2

Cultural Capital in HE and LE

\begin{tabular}{|c|c|c|c|c|c|c|}
\hline \multirow[t]{2}{*}{ Highest level of education achieved } & \multicolumn{3}{|c|}{ High Exposure } & \multicolumn{3}{|c|}{ Low Exposure } \\
\hline & $\begin{array}{c}\% \\
\text { mothers }\end{array}$ & $\begin{array}{c}\% \\
\text { fathers }\end{array}$ & $\begin{array}{c}\% \\
\text { both }\end{array}$ & $\begin{array}{c}\% \\
\text { mothers }\end{array}$ & $\begin{array}{c}\% \\
\text { fathers }\end{array}$ & $\begin{array}{c}\% \\
\text { both }\end{array}$ \\
\hline Unknown & 12.5 & 12.5 & 12.5 & 15.38 & 15.38 & 15.38 \\
\hline No studies or incomplete primary/secondary studies & 12.5 & 25 & 18.75 & 15.38 & 42.31 & 28.85 \\
\hline Primary or secondary studies & 50 & 0 & 25 & 34.62 & 19.23 & 26.93 \\
\hline Voluntary, non-university studies & 12.5 & 62.5 & 37.5 & 26.93 & 19.23 & 23.08 \\
\hline Graduate-level university studies: 3-5 year degree & 0 & 0 & 0 & 0 & 3.85 & 1.93 \\
\hline Postgraduate university studies: Master's degree & 12.5 & 0 & 6.25 & 3.85 & 0 & 1.93 \\
\hline Postgraduate university studies: PhD & 0 & 0 & 0 & 3.85 & 0 & 1.93 \\
\hline Number of books in the home & \multicolumn{3}{|c|}{ \% High Exposure } & \multicolumn{3}{|c|}{ \% Low Exposure } \\
\hline 0 to 10 & \multicolumn{3}{|c|}{12.5} & \multicolumn{3}{|c|}{19.23} \\
\hline 11 to 50 & \multicolumn{3}{|c|}{37.5} & \multicolumn{3}{|c|}{42.31} \\
\hline 51 to 100 & \multicolumn{3}{|c|}{37.5} & \multicolumn{3}{|c|}{26.92} \\
\hline 101 to 200 & \multicolumn{3}{|c|}{12.5} & \multicolumn{3}{|c|}{3.85} \\
\hline$>200$ & \multicolumn{3}{|c|}{0} & \multicolumn{3}{|c|}{7.69} \\
\hline
\end{tabular}


However, the percentages of both indicators (see Table 2) suggest that students with greater-than-average cultural capital tended to concentrate in the HE tracks, while students with lower-than-average cultural capital tended to concentrate in the LE track. The percentage of parents with education levels above the median (i.e., with voluntary studies, at any level) was 14.88 percentage points higher in HE than LE, and the percentage below the median (i.e., who did not complete primary/secondary studies) was 10.15 points higher in $\mathrm{LE}$ than $\mathrm{HE}^{2}$. There were also considerable differences amongst the fathers: most HE fathers $(62.5 \%)$ had completed voluntary studies (as compared with $23.08 \%$ of LE fathers), yet nearly half (42.31\%) of LE fathers had not completed primary or secondary education (as compared with $25 \%$ of $\mathrm{HE}$ fathers). Similarly, the percentage of families with more than 11 to 50 books was 11.54 points higher in HE than LE, while the percentage with less was 6.73 points higher in LE than HE.
According to the theoretical framework informing this study (Bourdieu, 1977), parents with greater cultural capital tend to be more familiar with academic knowledge and the means of expressing it, and are thus better equipped to ensure their children's academic success. More concretely, higher parental educational attainment correlates positively with children's learning-related behaviors, reading and mathematics skills (Morgan et al., 2009), and growing up in homes with many books (perhaps due to the value placed on reading) "endows children with tools that are directly useful in learning at school: vocabulary, information, comprehension skills ..." (Evans et al., 2010, p. 189). Overall, the higher levels of cultural capital present in the HE track may indicate stronger academic support at home.

Table 3

Economic Capital in HE and LE

\begin{tabular}{|c|c|c|c|c|c|c|c|c|}
\hline & \multicolumn{3}{|c|}{ High Exposure } & \multicolumn{3}{|c|}{ Low Exposure } \\
\hline \multicolumn{3}{|c|}{ Current or most recent occupation } & $\begin{array}{l}\% \\
\text { mothers }\end{array}$ & $\begin{array}{l}\% \\
\text { fathers }\end{array}$ & $\begin{array}{c}\% \\
\text { both }\end{array}$ & $\begin{array}{l}\% \\
\text { mothers }\end{array}$ & $\begin{array}{l}\text { \% } \\
\text { fathers }\end{array}$ & $\begin{array}{c}\% \\
\text { both }\end{array}$ \\
\hline \multicolumn{3}{|l|}{ Unknown } & 0 & 0 & 0 & 15.38 & 15.38 & 15.38 \\
\hline \multicolumn{3}{|c|}{ Not applicable (Absent parent) } & 0 & 0 & 0 & 11.54 & 3.85 & 7.69 \\
\hline \multicolumn{3}{|c|}{ Has never been employed } & 12.5 & 12.5 & 12.5 & 19.23 & 0 & 9.62 \\
\hline \multicolumn{3}{|l|}{ Unskilled workers } & 50 & 12.5 & 31.25 & 7.69 & 11.54 & 9.62 \\
\hline \multicolumn{3}{|c|}{$\begin{array}{l}\text { Artisan and skilled workers in agriculture, fishing, } \\
\text { manufacturing, construction, mining }\end{array}$} & 12.5 & 37.5 & 25 & 3.85 & 53.85 & 28.85 \\
\hline \multicolumn{3}{|c|}{$\begin{array}{l}\text { Workers in hospitality, security/protection, personal } \\
\text { services, salespeople, low-ranking military }\end{array}$} & 12.5 & 0 & 6.25 & 26.92 & 3.85 & 15.39 \\
\hline \multicolumn{3}{|c|}{$\begin{array}{l}\text { Technicians, support workers, administrative employees, } \\
\text { and small business owners }\end{array}$} & 12.5 & 12.5 & 12.5 & 7.69 & 7.69 & 7.69 \\
\hline \multicolumn{3}{|c|}{$\begin{array}{l}\text { Managers of companies or public administrations and } \\
\text { high-ranking officials }\end{array}$} & 0 & 12.5 & 6.25 & 3.85 & 0 & 1.93 \\
\hline \multicolumn{3}{|c|}{ Professionals, scientists, and scholars } & 0 & 12.5 & 6.25 & 3.85 & 3.85 & 3.85 \\
\hline $\begin{array}{l}\text { Number of IT devices } \\
\text { in the home }\end{array}$ & $\begin{array}{c}\text { \% High } \\
\text { Exposure }\end{array}$ & $\begin{array}{c}\text { \% Low } \\
\text { Exposure }\end{array}$ & \multicolumn{4}{|c|}{ Number of people in household } & $\begin{array}{l}\text { \% High } \\
\text { Exposure }\end{array}$ & $\begin{array}{l}\text { \% Low } \\
\text { Exposure }\end{array}$ \\
\hline Unknown & 12.5 & 7.69 & \multicolumn{4}{|l|}{2 to 3} & 37.5 & 26.92 \\
\hline 0 to 3 & 0 & 7.69 & \multicolumn{4}{|l|}{4 to 5} & 62.5 & 50 \\
\hline 4 to 6 & 12.5 & 34.62 & \multicolumn{4}{|l|}{6 to 7} & 0 & 15.38 \\
\hline 7 to 9 & 62.5 & 30.77 & \multicolumn{4}{|l|}{8 to 9} & 0 & 3.85 \\
\hline 10 to 12 & 12.5 & 19.23 & \multicolumn{4}{|l|}{10} & 0 & 3.85 \\
\hline \multirow[t]{2}{*}{$\begin{array}{l}\text { Median IT devices } \\
\text { in the home }\end{array}$} & $\begin{array}{c}\text { High } \\
\text { Exposure }\end{array}$ & $\begin{array}{c}\text { Low } \\
\text { Exposure }\end{array}$ & \multirow{2}{*}{\multicolumn{4}{|c|}{ Median IT devices/ household member }} & $\begin{array}{c}\text { High } \\
\text { Exposure }\end{array}$ & $\begin{array}{c}\text { Low } \\
\text { Exposure }\end{array}$ \\
\hline & 7 & 7.5 & & & & & 2.33 & 1.58 \\
\hline
\end{tabular}




\section{Economic Capital}

Economic capital is operationalized as parents' occupation, household size and IT devices in the home. To calculate central tendencies, occupation was placed on a numerical scale from 0 (unknown) to 7 (professionals) ${ }^{3}$, according to the categories in Table 3. Medians were then calculated for occupation, total household size, total number of IT devices, and number of IT devices per person. In the case of the latter, the number of devices reported by each student was divided by their total household size, and the resulting values were used to calculate the median IT devices per household member in each track.

As was the case with cultural capital, the medians for most indicators of economic capital were similar between tracks, but percentage-wise calculations reveal that students with greater-than-average economic capital were more frequently found in the HE track, and students with lowerthan-average economic capital were more frequently found in the LE track (see Table 3). In occupation, the median level for both tracks was 3 (artisans and skilled workers), and the percentage of parents with an occupational level above and below the median was similar in HE and LE, but parents working in the three most lucrative professions were nearly twice as frequent in the HE track $(25 \%)$ than in the LE track (13.47\%). Differences were particularly salient for fathers, with $37.5 \%$ of $\mathrm{HE}$ fathers in the three most lucrative positions, compared to $11.54 \%$ of LE fathers. In the LE track, "not applicable" was selected for $11.54 \%$ of mothers and $3.85 \%$ of fathers, indicating that these parents were not present (due to death, living elsewhere, etc.). No HE students selected "not applicable" for either parent.

Similarly, the median household size for both tracks was 4 , but nearly a quarter $(23.08 \%)$ of the LE students had 6 or more members in their household, as compared with $0 \%$ in LE. The most notable difference was in median IT devices per household member: there were 2.33 devices per household member in HE and only 1.58 in LE due to differences in family sizes. No students from the HE track reported having one device or less per family member, yet this was the case for $27.9 \%$ of LE students, over half of whom had less than one device per family member and were thus sharing devices. In addition to indicating lower economic capital in the LE track, this finding reveals a disadvantage for LE students learning semi-presentially during the COVID-19 pandemic.

\section{Unknown Responses in Educational and Occupational Levels}

Five students, four in LE and one in HE, did not indicate their parents' educational level, occupational level or both (see Tables 2 and 3). Although there is no way of interpreting their lack of response, it is important to note that the other indicators of socioeconomic status for these students were lower than those of their peers in both tracks: the median number of IT devices per household member was lower
(1.3), their median household size was larger (5 members), and they had fewer books at home (40\% had 0-10 books, $40 \%$ had $11-50$ books and $20 \%$ had $51-100$ books). Four of these five students were either immigrants or the children of immigrants, which may suggest a flaw in the questionnaire. The options offered were complex and based on the Spanish system, so participants whose parents studied elsewhere, worked multiple jobs or were unemployed may have found it difficult to check one box or another. In an improved version of this study, the options available would be condensed to those presented in Tables 2 and 3, instead of the long list used in the questionnaire.

\section{Teachers' Use of English in the Classroom}

n the questionnaire, students ranked the extent to which their English language and CLIL teachers used English in the classroom, from 1 (always) to 6 (never), when teaching content/explaining materials and when giving instructions about what to do in class. The median values in each category were calculated in HE and LE. For teaching/ explaining content, the median value was 1.5 ("always" or "almost always") in HE and 3 ("a lot") in LE. For giving instructions, the median value was 2.5 ("almost always" or "a lot") in HE and 3 ("a lot") in LE. In both cases, then, HE students perceived that their teachers used English more often than did LE students, but this difference was more marked when teaching content.

Statistical tests were run to assess the significance of the association between students' streaming (HE or LE) and their ranking of teacher's use of English. Regarding teacher's use of English when teaching content, the researcher first determined that this data was non-parametric: the Shapiro test on the HE data revealed a statistically significant difference between its distribution and the normal perfect curve $(p=0.036)$. Thus, the Wilcoxon signed-rank test, which is used with non-parametric data to test two variables for association, was run to assess the significance of the differences between HE and LE. The resulting p-value of 0.024 indicated a statistically significant association. As for giving instructions, this data was determined to be parametric: the Shapiro test did not indicate a difference between the normal perfect curve and the distribution of the HE data ( $p$ $=0.366)$ nor the LE data $(p=0.080)$, and the Variance test showed equality of variances in the two data sets $(p=0.475)$. Thus, the T-test, which is used with parametric data, was used to test the two variables for association. The p-value of 0.122 did not indicate a statistically significant difference between $\mathrm{HE}$ and LE in this case.

These results suggest that while LE students already receive fewer hours of English per week, studying in $23 \%$ immersion as compared to $36 \%$ in the HE track at this school, the less frequent use of English in their CLIL classrooms further reduces their exposure to English. Not only are the subjects studied in English fewer and less academic in LE, but they may thus also provide more limited opportunities to practice receptive skills, further distancing students from 
the target language. This observation provides evidence for the Matthew effect described in Somers and Llinares (2021, p. 852):

High proficient students receive more opportunity to develop English in contexts that will allow them to transfer that proficiency later on, whereas low proficient students find themselves in a situation where because of the limited exposure and academic status of the subjects, CLIL is unable to do much for them in the future.

Importantly, the data reported here reflect students' perceptions of teacher's use of English, not their actual use of the language. To better understand how, when and why teachers use this language in each track, researchers should observe and record classroom interaction. Even so, students' perceptions of English use are more likely to influence their motivation (Somers \& Llinares, 2021), which is discussed in the following subsection.

\section{CLIL Motivation}

7 o measure motivation, students were asked to indicate the extent to which they agreed with a series of statements, from 1 (strongly agree) to 5 (strongly disagree), as explained above in the section "Instrument." Thus, a lower score indicated greater motivation. The average score for each type of motivation (intrinsic and instrumental) was calculated for each student, and the medians of these averages were then calculated for HE and LE. For intrinsic motivation, the median was 1.5 in HE and 2.33 in LE. For instrumental motivation, the median was 1.25 in HE and 1.5 in LE. In other words, students in both tracks were more instrumentally than intrinsically motivated, meaning that their motivation was based in the achievement of some ulterior motive (e.g., job prospects, tertiary studies) more than the enjoyment of CLIL for its own sake, and HE students were more motivated than LE students in both categories.

Statistical tests were run to assess the significance of the association between students' streaming (HE or LE) and each type of motivation. The data on intrinsic motivation was parametric: the $p$-values given by the Shapiro test ( $p$ $=0.129$ for HE, $\mathrm{p}=0.154$ for LE) and Variance test $(\mathrm{p}=$ 0.151 ) indicate that this data follows the normal perfect curve and has equality of variances. Thus, the T-test for parametric data was run; it gave a p-value of 0.009 , demonstrating that the HE students were significantly more intrinsically motivated (to participate in CLIL for its own sake) than their LE counterparts. The data on instrumental motivation was non-parametric: the p-values given by the Shapiro test $(p=0.002$ for HE, $p=0.012$ for LE) indicate that neither data set follows the normal perfect curve. Thus, the Wilcoxon signed-rank test for non-parametric data was run. It gave a $p$-value of 0.814 , indicating that the difference in instrumental motivation in HE and LE was not statistically significant. The medians suggest that students in both tracks are similarly aware of the importance of English for their academic and professional futures.

At this school, the differences between HE and LE were more marked for intrinsic than instrumental motivation. While all students generally agreed that studying subjects in English was useful for them in their future studies, finding a job, gaining respect, and so on, LE students at this school enjoyed learning and participating in these subjects to a lesser extent than their HE peers. As Somers and Llinares (2021, p. 845) explain, intrinsic motivation "is closely related to what goes on in CLIL classrooms." It may therefore be related to how teachers engage students to deal with content in a language they are less proficient in, i.e., the teaching strategies and activities used in the classroom. Certainly, Llinares and Evnitskaya (2021) found that teachers enhanced students' higher order thinking skills to a greater extent in HE than LE by using more appraisal resources when checking their knowledge and exploring their views. Future research should explore the relationship between these differences in teaching strategies and students' motivation.

\section{Limitations}

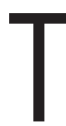
he present study has explored how streaming may be related to SES, teachers' use of English and students' motivation at one school in the MBP. However, it is not, nor does it claim to be, representative of this program: since the data was collected at only one high school, the results are limited to that context. To better understand how these variables interact, a larger sample of schools from multiple socioeconomic contexts is needed. Regarding SES, it should also be highlighted that no formula was used to determine the overall SES of each student, as is often done in 
sociological and educational research (e.g., National Center for Educational Statistics, 2012) to achieve a more holistic measure than that which was presented here. Still, not using a formula has allowed the researcher to have a more indepth look at the relative weight of different indicators: for example, that the disparity in parental occupational level between HE and LE is greater for fathers than mothers. It has also allowed me to analyze some indicators of students' SES when they did not respond to all items on the questionnaire. This brings me to the next limitation: certain items (namely, occupation and education) were not accessible to immigrant students, creating a gap in the data. An improved version of the questionnaire would present more general occupational and educational categories to avoid this pitfall. Finally, a more representative sample of the LE track would have included students from each group, rather than only the highest and lowest performing groups. A larger sample of HE students would have also been useful. Unfortunately, neither was possible at the time of the study due to the groups' availability and the number of students in each track.

\section{Concluding Remarks}

$\mathrm{n}$ this study, three differences between the HE and LE tracks at one school in a working-class area were examined: socioeconomic indicators, teachers' use of English in the classroom, and CLIL motivation. The results showed that, in this context, median levels of students' cultural and economic capital were only slightly higher in HE than LE, but students with either more or less capital than the median were more frequently found in HE or LE, respectively (Research Question 1). Indeed, the lowest SES students (with the greatest family sizes, fewest books, fewest IT devices per household member, and least educated parents) were found in the LE track. However, research suggests that more extensive, pedagogically informed exposure to English may benefit these students: Lorenzo et al. (2021) showed that low SES students perform better academically at bilingual schools without streaming, and Somers and Llinares (2021) demonstrated that HE confers both linguistic capital (foreign language knowledge) and cultural capital (prestige). It seems that at this school higher SES students were more often placed in the HE strand and thus granted the opportunity to accumulate this additional capital.

During the 2020-2021 school year, the full benefits of CLIL were only offered to eight students in year 10 at the school in this study. The rest studied in LE groups where, in addition to receiving fewer hours of English, they reported that their CLIL and English teachers used this language less frequently (Research Question 2) and that they enjoyed their CLIL classes less. While all students recognized the utility of studying in English for their futures, as demonstrated by their high instrumental motivation levels (Research Question 4), the intrinsic motivation of LE students was

\section{${ }^{66}$ At this school higher SES students were more often placed in the HE strand and thus granted the opportunity to accumulate this additional capital."}

significantly lower than that of HE students (Research Question 3). If students do not enjoy their classes, they may be less likely to participate in them and, in turn, exhibit worse educational outcomes. At this school, such a scenario would disproportionately affect the lowest SES students, who were most often found in LE groups. Let us recall that, overall, the SES of students in this town is quite low. It is striking that in this context, so few students form part of the HE track: eight in grade 10, eighteen in grade 9, eight in grade 8 and nineteen in grade 7. For comparison, the middle-class bilingual school studied in Fernández-Agüero and HidalgoMcCabe (2020) had 134 students in HE and 23 in LE during grade 7 . Although comparisons between schools go beyond the scope of this study, they provide meaningful inspiration for future research. Such work should compare streaming at schools of different overall SES levels, analyzing the percentages of students enrolled in HE and LE and students' median SES in each track.

\section{Notes}

1 Bourdieu (1977, 1986) and Block (2014) use the term "social class" rather than "socioeconomic status." The two are often used interchangeably in sociological and sociolinguistic research (e.g., Babbie, 2011), but operational definitions of the latter are usually limited to some combination of income, education, and occupation, whereas the former also encompasses attitudes and tastes developed during one's upbringing (Bourdieu's (1977) "habitus").

2 This figure only reflects interpretable responses, thus excluding the "unknown" responses to be discussed in the section "Unknown Responses in Educational and Occupational Levels."

3 This scale excludes parents from the "not applicable" category, which represented parents absent from their children's lives for any reason. 


\section{References}

Babbie, E. (2011). The Basics of Social Research (5th ed.). Wadsworth, CENGAGE Learning.

Block, D. (2012). Class and SLA: Making Connections. Language Teaching Research, 16(2), 188-205. https://doi.org/10.1177/1362168811428418

Block, D. (2014). Social Class in Applied Linguistics. Routledge.

Bourdieu, P. (1977). Cultural Reproduction and Social Reproduction. In J. Karabel \& A. H. Halsey (Eds.), Power and Ideology in Education (pp. 487-511). Oxford University Press.

Bourdieu, P. (1986). The forms of capital. In J.F. Richardson (Ed.), Handbook of theory of research for sociology of education (pp. 241-58). Greenwood Press.

Broer, M., Bai, Y., \& Fonseca, F. (2019). Socioeconomic Inequality and Educational Outcomes: Evidence from Twenty Years of TIMSS. IEA Research for Education, A Series of In-depth Analyses Based on Data of the International Association for the Evaluation of Educational Achievement.

https://doi.org/10.1007/978-3-030-11991-1

Christie, F. (2005). Classroom discourse analysis: A functional perspective. Continuum.

Comunidad de Madrid. (2015). Tipificación socioeconómica y laboral del territorio de la Comunidad de Madrid: Lecciones aprendidas. Madrid: Consejería de Economía, Empleo y Hacienda de la Comunidad de Madrid. http:// www.madrid.org/bvirtual/BVCM015624-1.pdf

Comunidad de Madrid. (2016). Madrid, Comunidad Bilingüe 2015-2016. Madrid, a BilingualCommunity 2015-2016. Madrid: Consejería de Educación, Juventud y Deporte. http://www.madrid.org/bvirtual/BVCM016309.pdf

Comunidad de Madrid. (2020). Mercado de trabajo en los municipios madrileños junio 2020. Madrid: Consejería de Economía, Empleo y Competitividad. http://www. madrid.org/bvirtual/BVCM013420-2020-01.pdf

European Commission. (1995). White paper on education and training. Teaching and learning. Towards the learning society. Brussels. https://op.europa.eu/en/ publication-detail/-/publication/d0a8aa7a-5311-4eee904c-98fa541108d8/language-en

European Commission. (n.d.). About multilingualism policy. http://ec.europa.eu/education/policies/multilingualism/ about-multilingualism-policy_en
Evans, M. D., Kelley, J., Sikora, J., \& Treiman, D. J. (2010). Family scholarly culture and educational success: Books and schooling in 27 nations. Research in Social Stratification and Mobility, 28(2), 171-197. http://doi.org/10.1016/j.rssm.2010.01.002

Gardner, R. C. (1985). Social Psychology and Second Language Learning: The Role of Attitudes and Motivation. Edward Arnold.

Gil Flores, J. (2013). Medición del nivel socioeconómico familiar en el alumnado de Educación Primaria. Revista de Educación, 362, 298-322.

http://doi.org/10.4438/1988-592X-RE-2011-362-162

Horn, D. (2013). Diverging performances: The detrimental effects of early selection on equality of opportunity in Hungary. Research in Social Stratification and Mobility, 32, 25-43.

https://doi.org/10.1016/j.rssm.2013.01.002

Instituto de Estadística de la Comunidad de Madrid. (2019). T19M5 - Población por municipios, distritos y barrios de Madrid y zonas estadísticas según nacionalidad para cada sexo. Padrón municipal 2019.

http://www.madrid.org/iestadis/fijas/estructu/ demograficas/padron/descarga/pc19t19_m5.xls

Fernández-Agüero, M. \& Hidalgo-McCabe, E. (2020). CLIL Students' Affectivity in the Transition between Education Levels: The Effect of Streaming at the Beginning of Secondary Education. Journal of Language, Identity \& Education. https://doi.org/10.1080/15348458.2020.1795864

Llinares, A. \& Evnitskaya, N. (2021). Classroom Interaction in CLIL Programs: Offering Opportunities or Fostering Inequalities? TESOL Quarterly, 55(2), 366-397. https://doi.org/10.1002/tesq.607

Lorenzo, F., Granados, A., \& Rico, N. (2021). Equity in Bilingual Education: Socioeconomic Status and Content and Language Integrated Learning in Monolingual Southern Europe. Applied Linguistics, 42(3), 393-413. https://doi.org/10.1093/applin/amaa037

Mediavilla, M., Mancebón, M. J., Gómez- Sancho, J. M., \& Pires, L. (2019). Bilingual Education and School Choice: A Case Study of Public Secondary Schools in the Spanish Region of Madrid. IEB Working. http:// diposit.ub.edu/dspace/bitstream/2445/134081/1/IEB1901_Mediavilla\%2bet.al.pdf

Morgan, P. L., Farkas, G., Hillemeier, M. M., \& Maczuga, S. (2009). Risk factors for learning-related behavior problems at 24 months of age: Population-based estimates. Journal of Abnormal Child Psychology, 37, 401-413. https://doi.org/10.1007/s10802-008-9279-8 
National Center for Educational Statistics. (2012). Improving the Measurement of Socioeconomic Status for the National Assessment of Educational Progress: A Theoretical Foundation. https://nces.ed.gov/ nationsreportcard/pdf/researchcenter/Socioeconomic Factors.pdf

Somers, T., \& Llinares, A. (2021). Students' motivation for content and language integrated learning and the role of programme intensity. International Journal of Bilingual Education and Bilingualism, 24(6), 839-854.

https://doi.org/10.1080/13670050.2018.1517722

Spanish Ministry of Education, Culture and Sport. (2017, May 6). Order ECD/393/2017, of 4 May, regulating the final assessment for Compulsory Secondary Education in the academic year 2016/2017. Boletin Oficial del Estado, 108, 36868-97.

https://www.boe.es/eli/es/o/2017/05/04/ecd393/con

Spanish Ministry of Education, Youth and Sport. (2017, April 7). Order 972/2017, of 7 April, regulating the SpanishEnglish bilingual high schools in the Community of Madrid. http://www.madrid.org/wleg_pub/secure/ normativas/contenidoNormativa.jsf?opcion=VerHtml\& nmnorma $=9744 \&$ cdestado $=$ P\#no-back-button

Van Mensel, L., Hilligsmann, P., Mettewie, L., \& Galand, B. (2020). CLIL, An Elitist Language Learning Approach? A Background Analysis of English and Dutch CLIL Pupils in French-speaking Belgium. Language, Culture and Curriculum, 33(1), 1-14.

https://doi.org/10.1080/07908318.2019.1571078 